Фармацевтична технологія, біофармація, гомеопатія Pharmaceutical technology, biopharmacy, homeopathy

Рекомендована д. фрармац. наук. профр. Т. А. Грошовим УДК 615.014.23:615.26

DOI 10.11603/2312-0967.2018.3.9453

\title{
СУЧАСНІ ПІДХОДИ ДО ЗАСТОСУВАННЯ ЕМУЛЬГАТОРІВ ТА КОНСЕРВАНТІВ У СКЛАДІ ДЕРМАТОЛОГІЧНИХ ЛІКАРСЬКИХ ЗАСОБІВ
}

\author{
(c) І. Р. Пелех, С. Б. Білоус \\ Львівський національний медичний університет імені Данила Галицького \\ iryna.p.r.8@gmail.com
}

\begin{abstract}
Мета роботи. Дослідити номенклатуру емульгаторів і консервантів, які найчастіше застосовуються у складі сучасних м'яких лікарських засобів, проаналізувати дані наукової літератури щодо розробки нових лікарських засобів емульсійного типу.

Матеріали і методи. Використано методи інформаційного пошуку та аналізу даних літератури.

Результати й обговорення. На сьогодні значну кількість дерматологічних лікарських засобів становлять лікарські засоби емульсійного типу з високим вмістом водної фази - це м'які лікарські засоби для нашкірного застосування та лікарські косметичні креми. При виготовленні емульсійних засобів важливим $€$ вибір допоміжних речовин, зокрема емульгаторів та консервантів, які за структурою здебільшого $€$ поверхнево-активними речовинами та часто зумовлюють побічні реакції. Практично всі синтетичні поверхнево-активні речовини здатні видаляти 3 поверхні тіла жироподібні речовини, зокрема тонку захисну плівку, яку утворюють сальні та потові залози шкіри. Тому перспективним $€$ використання біогенних поверхнево-активних речовин як емульгаторів та консервантів. Проведено вивчення номенклатури емульгаторів і консервантів, які застосовуються у складі м'яких емульсійних лікарських засобів, зареєстрованих у Державному реєстрі лікарських засобів України. В результаті проведеного дослідження встановлено, що як емульгатори 1-го роду у складі емульсійних лікарських засобів в основному використовують полісорбати, як емульгатори 2-го роду - цетостеариловий спирт та ланолін.

Висновки. Враховуючи, що синтетичні поверхнево-активні речовини можуть спричиняти значні побічні реакції та $€$ сильними алергенами, актуальним $€$ дослідження біогенних ПАР як перспективних емульгаторів та консервантів, зокрема вивчення їх емульсійної та консервуючої здатності, що буде сприяти розширенню номенклатури допоміжних речовин для емульсійних лікарських та косметичних засобів.
\end{abstract}

Ключові слова: емульгатори; консерванти; поверхнево-активні речовини; емульсії; лікарські засоби; лікарські косметичні засоби.

Вступ. На сьогодні підвищений інтерес спостерігається до створення лікарських засобів для нашкірного застосування та лікарських косметичних кремів у формі емульсій [1, 2]. Саме такі засоби вимагають застосування великої кількості допоміжних речовин, зокрема емульгаторів, консервантів, солюбілізаторів $[1,3]$. Тому пошук нових допоміжних речовин для застосування у складі лікарських та косметичних засобів, які були б не токсичними, не алергенними та безпечними для людини, $є$ актуальним.

Матеріали і методи. У роботі використано методи інфрормаційного пошуку та аналізу даних літератури.

Результати й обговорення. При розробці лікарського чи косметичного засобу у вигляді емульсійної форми важливим етапом $є$ вибір допоміжних речовин, які б дозволили одержати безпечний для застосування засіб. Такими допоміжними речовинами, які вимагають особливої уваги, є емульгатори та консерванти [4].

Емульгатори здебільшого є поверхнево-активними речовинами (ПАР), молекули яких мають дифріль- ну будову, формують пограничний шар на поверхні рідин, що не змішуються, який знижує поверхневий натяг, і завдяки чому з'являється можливість утворення емульсії [3, 4].

Основні технологічні властивості ПАР визначаються значенням гідрофрільно-ліпофрільного балансу (ГЛБ) їх молекул, що коливається від 1,0 до 20,0. Чим більше значення ГЛБ, тим більше проявляється здатність ПАР утворювати та стабілізувати емульсії типу м/в, і навпаки, чим менше значення ГлБ, тим яскравіше проявляється здатність до створення і стабілізації емульсій типу в/м. Емульгатори відповідають за взаємний розподіл двох фраз, консистенцію емульсійної системи, її пластичні властивості, в'язкість, пористість структури, плинність, розмір частинок дисперсної фрази, рівномірність їх розподілу в дисперсійному середовищі $[3,4]$.

При виборі емульгаторів для стабілізації емульсійних систем необхідно враховувати механізм їх стабілізаційної дії, токсичність, величину рН, хімічну сумісність $з$ іншими компонентами емульсії тощо. Для

ISSN 2312-0967. Фармацевтичний часопис. 2018. № 3 
стабілізації емульсійних засобів переважно використовуються від 0,1 до 10 \% емульгаторів [5].

При виготовленні емульсій типу м/о особливу увагу слід також приділяти консервуванню, оскільки зовнішня водна фраза є сприятливим середовищем для розвитку бактерій та плісневих грибів [4].

Основна мета введення консервантів в емульсійні засоби - захист від мікробіологічного ураження в процесі зберігання та застосування засобу [4].

Більшість консервантів також $є$ поверхнево-активними речовинами, які здатні спричиняти побічні есректи, зокрема й алергічні реакції.

При взаємодії зі шкірою і слизовими оболонками ПАР суттєво впливають на їх стан і лікувальний ефект лікарських та косметичних засобів. Поверхнево-активні речовини взаємодіють із цитоплазматичною мембраною клітини, деполяризуючи ії. Синтетичні ПАР можуть проникати в організм людини навіть крізь непошкоджену шкіру. Швидкість надходження ПАР у організм людини залежить від їх фрізико-хімічних властивостей, концентрації та тривалості контакту зі шкірою [6]. Практично всі поверхнево-активні речовини здатні видаляти 3 поверхні тіла всі жироподібні продукти, зокрема тонку захисну плівку, яку утворюють сальні та потові залози шкіри [3].

Аналіз наукової літератури показав, що побічну дію дерматологічних засобів найчастіше пов'язують 3 такими консервантами та емульгаторами (табл. 1) $[1,2,4,6]$.

Вирішенням проблеми побічної дії емульгаторів та консервантів може стати застосування біогенних поверхнево-активних речовин, так званих біоПАР. Зокрема перспективним у даному випадку $€$ використання біокомплексу PS - біогенної повернево-
Фармацевтична технологія, біофармація, гомеопатія Pharmaceutical technology, biopharmacy, homeopathy

активної речовини, синтезованої бактеріями роду Pseudomonas. Біокомплекс PS являє собою пасту до складу якої входить рамноліпід, альгінат та вода. Субстанція розроблена у Відділенні фрізико-хімії горючих копалин Інституту фрізико-органічної хімії та вуглехімії імені Л. М. Литвиненка НАН України [7]. Бактерії роду Pseudomonas є активними продуцентами поверхнево-активних продуктів. Можливість застосування біокомплексу PS зумовлена такими властивостями: низький поверхневий та міжфазний натяг, емульгувальна, піноутворювальна та мийна здатність [7].

БіоПАР мають такі ж фрізико-хімічні властивості, як і синтетичні сурфактанти: для них відомі значення критичної концентрації міцелоутворення (ККМ), гідрофрільно-ліпофрільного балансу (ГЛБ), поверхневого і міжфазного натягу та інші [8]. БіоПАР, для яких величина ГЛБ менше 6, утворюють стабільні емульсій типу «вода/олія», а при значенні ГЛБ 10-18 - емульсії типу «олія/вода». Вони можуть стабілізувати (емульгатори) і дестабілізувати (деемульгатори) емульсії, а їх здатність до солюбілізації і утворення міцел, зумовлюють активність цих сполук відносно різних біологічних об'єктів [8, 9].

3 метою вибору емульгаторів та консервантів, 3 якими доцільно порівнювати емульгуючу та консервуючу здатність біокомплексу PS, ми провели вивчення номенклатури емульгаторів і консервантів, які застосовуються у складі сучасних м'яких лікарських засобів емульсійного типу. Зокрема проаналізовано склад лікарських засобів для нашкірного застосування, зареєстрованих в Державному реєстрі лікарських засобів України станом на травень 2018 р., які належать до групи D за ATC класифрікацією [10], та проведено ви-

Таблиця 1. Побічна дія емульгаторів і консервантів

\begin{tabular}{|c|c|}
\hline Назва & Побічна дія \\
\hline \multicolumn{2}{|c|}{ Емульгатори } \\
\hline Віск неіонний емульгувальний & Може спричинити подразнення очей. \\
\hline Естери сорбітану & $\begin{array}{l}\text { При місцевому застосуванні можуть спричинити } \\
\text { подразнення шкіри. }\end{array}$ \\
\hline Ланолін & $\begin{array}{l}\text { Ланолін не має токсичних ефектів, але він практично } \\
\text { завжди містить у складі домішки пестицидів. Саме } \\
\text { домішки пестицидів у ланоліні можуть спричинити } \\
\text { алергію. }\end{array}$ \\
\hline Спирти цетиловий та стеариловий & $\begin{array}{l}\text { У пацієнтів з дерматозами можуть спричинити алергічні } \\
\text { реакції гіперчутливості }\end{array}$ \\
\hline \multicolumn{2}{|c|}{ Консерванти } \\
\hline Консерванти на основі парабенів & $\begin{array}{l}\text { Здатні накопичуватись в онкологічних пухлинах, а } \\
\text { також індукувати їх утворення. Негативно впливають } \\
\text { на репродуктивну та гормональну систему. }\end{array}$ \\
\hline Консерванти донори формальдегіду & $\begin{array}{l}\text { Ушкоджують ДНК, верхні дихальні шляхи, слизові } \\
\text { оболонки та очі. Здатні викликати рак легень. }\end{array}$ \\
\hline Кислота сорбінова & $\begin{array}{l}\text { Може викликати подразнення шкіри, алергічні } \\
\text { кон'юнктивіти }\end{array}$ \\
\hline
\end{tabular}

ISSN 2312-0967. Pharmaceutical review. 2018. № 3 
Фармацевтична технологія, біофармація, гомеопатія Pharmaceutical technology, biopharmacy, homeopathy

вчення даних наукової літератури щодо розробки нових лікарських засобів емульсійного типу.

Встановлено, що у групі D зареєстровано 513 лікарських засобів, у складі яких $є$ емульгатори або консерванти, або обидві групи вказаних компонентів, 3 них 147 гелів (29\%), у т. ч. 2 емульгелі, 12 емульсій для нашкірного застосування (2 \%), 137 кремів (27\%) та 217 мазей (42 \%) ( рис. 1).

До лікарських засобів емульсійного типу належать, а відповідно обов'язково містять у складі одночасно емульгатори і консерванти, креми, рідкі емуль- сії для нашкірного застосування та деякі гелі і мазі. Аналіз складу допоміжних речовин даних засобів показав, що як емульгатори 1-го роду для створення емульсійних лікарських засобів, в основному, використовуються полісорбати, як емульгатори 2-го роду найчастіше зустрічаються цетостеариловий спирт та ланолін. Як консерванти до складу емульсійних лікарських засобів для нашкірного застосування найчастіше входять парабени або їх суміші, а також спирт бензиловий. Результати дослідження наведено у таблиці 2 [10].

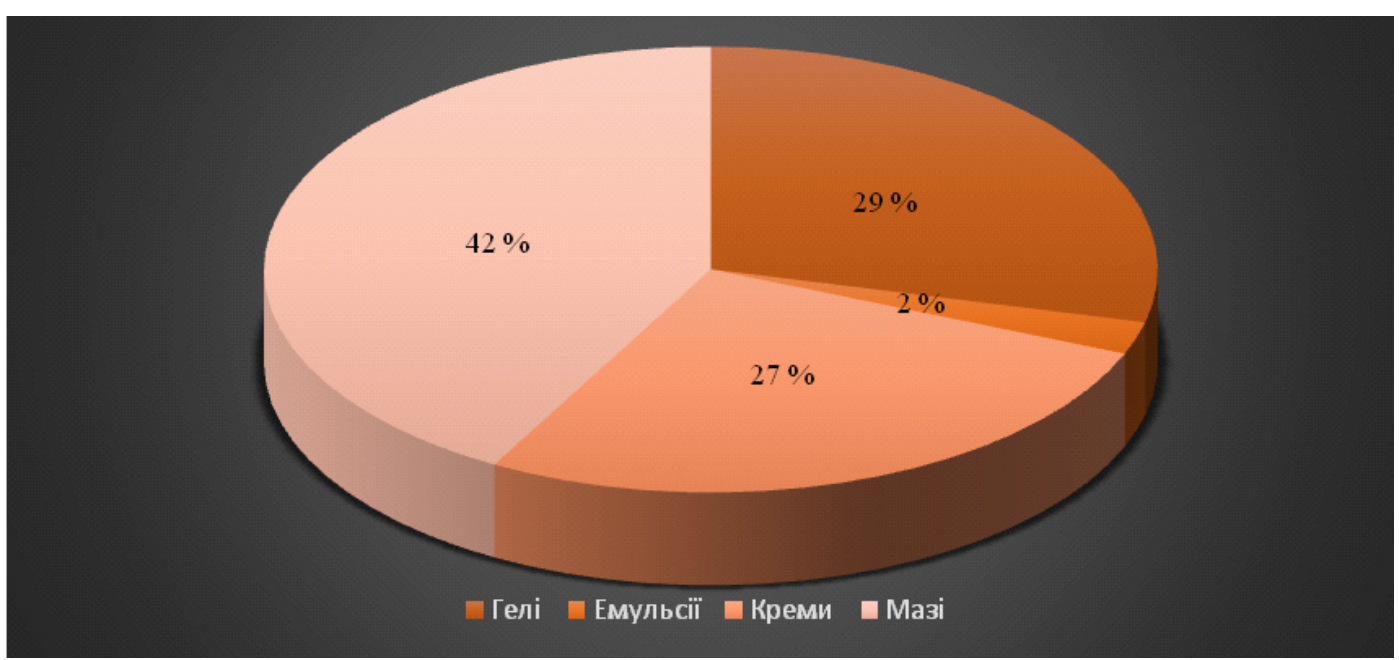

Рис. 1. Розподіл м'яких лікарських засобів за лікарськими формами.

Таблиця 2. Емульгатори та консерванти, які застосовують у складі емульсійних лікарських засобів

\begin{tabular}{|c|c|c|}
\hline \multicolumn{3}{|c|}{ Емульгатори } \\
\hline Назва & Торгова назва засобу & Форма випуску \\
\hline 1 & 2 & 3 \\
\hline Полісорбати & $\begin{array}{l}\text { Преднітоп, Карізон, Ламіфраст, Екзодерил, } \\
\text { Канеспор, Тербізил, Естезифрін, Канестен, } \\
\text { Травоген, Пенцикловір, Дермазин, Ламізил, } \\
\text { Фузікутан, Зіклара, Алдара, Кераворт, Дермокас, } \\
\text { Травокорт, Кловейт, Екзодерм, Дермазол, Кетодін, } \\
\text { Нізорал, Пімафукорт, Солантра }\end{array}$ & Крем \\
\hline Ланолін & $\begin{array}{l}\text { Ломексин, Пантекрем, Бепантен, Хепідерм, } \\
\text { Судокрем }\end{array}$ & Крем, мазь \\
\hline $\begin{array}{l}\text { Спирт цетостеариловий } \\
\text { емульгувальний }\end{array}$ & $\begin{array}{l}\text { Ліпстер, Белодерм, Бетазон, Елідел, Кетоконазол, } \\
\text { Ацикловір, Бетазон плюс, Рятівник, Тридерм, } \\
\text { Белогент, Вратизолін, Содерм, Локоїд крело }\end{array}$ & Крем, емульсія \\
\hline \multicolumn{3}{|c|}{ Консерванти } \\
\hline Назва & Торгова назва засобу & Форма випуску \\
\hline $\begin{array}{l}\text { Метилпарагідроксибензоат + } \\
\text { пропілпарагідроксибензоат }\end{array}$ & $\begin{array}{l}\text { Бетлібен, Халоват, Повекорт, Момат крем, Делор, } \\
\text { Розамет, Дермазин, Залаїн, Зіклара, Алдара, } \\
\text { Кераворт, Дермокас, Кандід-Б, Пімафукорт, } \\
\text { Белакне, Солантра, Аргосульфан, Фузідерм, } \\
\text { Пімафруцин, Вратизолін }\end{array}$ & Крем, мазь \\
\hline Метилпарагідроксибензоат & $\begin{array}{l}\text { Мезодерм, Елозон, Скін-кап, Карізон, Аргедин } \\
\text { босналек, Триакутан, Бетаметазон, Флуцар, } \\
\text { Псорікап, Содерм }\end{array}$ & Крем, емульсія \\
\hline
\end{tabular}

ISSN 2312-0967. Фармацевтичний часопис. 2018. № 3 
Фармацевтична технологія, біофармація, гомеопатія Pharmaceutical technology, biopharmacy, homeopathy

Продовження табл. 2

\begin{tabular}{|l|l|c|}
\hline \multicolumn{1}{|c|}{1} & \multicolumn{1}{|c|}{2} & \multicolumn{1}{|c|}{3} \\
\hline Пропілпарагідроксибензоат & Локоїд ліпокрем & Крем, емульсія \\
\hline Хлоркрезол & Клобескін, Дермовейт, Екодакс & Крем \\
\hline Спирт бензиловий & Адвантан, Преднітоп, Ламісраст, Екзодерил, & Крем, емульсія, емульгель \\
& Канеспор, Тербізил, Канестен, Ламізил, & \\
& Бактробан, Онабет, Зіклара, Алдара, Кераворт, & \\
& Елідел, Бетазон, Кандід-Б, Локоїд ліпокрем, & \\
& Екзодерм, Ламідерм, Нафтиоін, Приора, & \\
& Адвантан, Феністил емульсія & \\
\hline
\end{tabular}

Як емульгатори використовують також інші речовини, зокрема віск бджолиний, спирт поліоксиетилен2-стеариловий, спирт міристиловий. Як консерванти застосовують гексиленгліколь, кислоту сорбінову, бензалконію хлорид, однак вони входять до складу незначної кількості засобів.

При розробці м'яких лікарських засобів емульсійного типу в останні роки вивчають такі емульгатори, як цетиловий спирт, а як консерванти суміш - калію сорбату та саліцилової кислоти, які використано для приготування емульгелю для лікування андрогенної алопеції [11]. Також досліджуються амфіфрільні поверхнево-активні речовини на основі промелітового діангідриду, які здатні солюбілізувати речовини гідрофрільної та ліпофрільної природи, а також можуть використовуватись як стабілізатори емульсійних систем [12].

Для створення стійкої емульсійної системи 1-го роду необхідно застосовувати значну кількість емульгаторів, що може спричинити місцеве подразнення та руйнування шкірно-епідермального бар'єру. Саме тому застосовують поєднання емульгаторів 1-го та 2-го роду, а також до складу емульсійних засобів вводять високомолекулярні сполуки. Такий підхід застосовано при розробці лікарського косметичного засобу для застосування при андрогенній алопеції використано твін-20 в комбінації з ПАР олії солодкого мигдалю як емульгатор 1-го роду, а також ланолін еркалан із цетиловим спиртом як емульгатор 2-го роду [13]. При розробці мазі хондропротекторної дії використано як емульгатор 1-го роду гліцеролу моностеарат та полісорбат 80, як емульгатор 2-го роду - цетостеариловий спирт та макроголу стеарат [14].

Висновки. Вибір допоміжних речовин у складі лікарських та лікарських косметичних засобів для застосування у дерматології $€$ надзвичайно важливим питанням. Враховуючи негативний вплив поверхенево-активних речовин на шкіру, актуальним $€$ дослідження біоПАР як перспективних емульгаторів та консервантів, встановлення їх емульсійної та консервуючої здатності порівняно з іншими широко застосовуваними речовинами даного напрямку дії, що буде сприяти розширенню номенклатури допоміжних речовин.

\title{
СОВРЕМЕННЫЕ ПОДХОДЫ К ПРИМЕНЕНИЮ ЭМУЛЬГАТОРОВ И КОНСЕРВАНТОВ В СОСТАВЕ ДЕРМАТОЛОГИЧЕСКИХ ЛЕКАРСТВЕННЫХ СРЕДСТВ
}

\author{
И. Р. Пелех, С. Б. Билоус \\ Львовский национальный медицинский университет имени Данила Галицкого \\ iryna.p.r.8@gmail.com
}

Цель работы. Исследовать номенклатуру эмульгаторов и консервантов, которые применяются в составе современных мягких лекарственных средств, проанализировать данные научной литературы по разработке новых лекарственных средств эмульсионного типа.

Материалы и методы. Использованы методы информационного поиска и анализа данных литературы.

Результаты и обсуждение. На сегодня значительное количество дерматологических лекарственных средств составляют лекарственные средства эмульсионного типа с высоким содержанием водной фразы - это мягкие лекарственные средства для накожного применения и лекарственные косметические кремы. При изготовлении эмульсионных средств важен выбор вспомогательных веществ, в частности эмульгаторов и консервантов, которые по своей структуре преимущественно являются поверхностно-активными веществами и часто вызывают побочные реакции. Практически все синтетические поверхностно-активные вещества способны удалять с поверхности тела все жироподобные продукты, в частности тонкую защитную пленку, которую образуют сальные и потовые железы кожи. Поэтому перспективным является использование биогенных поверхностно-активных веществ в качестве эмульгаторов и консервантов. Проведено изучение номенклатуры эмульгаторов и консервантов,

ISSN 2312-0967. Pharmaceutical review. 2018. № 3 
Фармацевтична технологія, біофармація, гомеопатія

Pharmaceutical technology, biopharmacy, homeopathy

которые применяются в составе дерматологических эмульсионных лекарственных средств, зарегистрированных в Государственном реестре лекарственных средств Украины. В результате проведенного исследования установлено, что в качестве эмульгаторов 1-го рода в составе эмульсионных лекарственных средств в основном используется полисорбаты, как эмульгаторы 2-го рода - цетостеариловый спирт и ланолин.

Выводы. Учитывая, что синтетические поверхностно-активные вещества могут вызывать значительные побочные реакции и являются сильными аллергенами, актуальным является исследование биогенных ПАВ как перспективных эмульгаторов и консервантов, установление их эмульсионной и консервирующей способности, что будет способствовать расширению номенклатуры вспомогательных веществ для эмульсионных лекарственных и косметических средств.

Ключевые слова: эмульгаторы; поверхностно-активные вещества; эмульсии; консерванты; лекарственные средства; лекарственные косметические средства.

\title{
MODERN APPROACHES TO USE EMULATORS AND CONSERVATIVES IN THE COMPOSITION OF DERMATOLOGICAL DRUGS
}

\author{
I. R. Pelekh, S. B. Bilous \\ Danylo Halytsky Lviv National Medical University \\ iryna.p.r.8@gmail.com
}

The aim of the work. Study the nomenclature of emulsifiers and antimicrobial preservatives, used in modern semi-solid drugs, data analysis of scientific literature on the development of new drugs emulsion type.

Materials and Methods. Methods of information retrieval and analysis of literature data are used.

Results and Discussion. To date, a large number of dermatological preparations are medicines of emulsion type with a high content of the water phase - these are semi-solid preparations for the skin and medicinal cosmetic creams. In the manufacture of emulsion preparation, it is important to select the auxiliary substances, in particular emulsifiers and antimicrobial preservatives, which are mainly surfactants by their structure, and often cause side reactions. Practically all synthetic surface-active substances can remove all fatty products from the body surface, in particular a thin protective film that forms sebaceous and sweat glands of the skin. Therefore, it is promising to use biogenic surfactants as emulsifiers and preservatives. The study of the range of emulsifiers and antimicrobial preservatives used in semi-solid emulsion registered in the State Register of Medicinal Products of Ukraine was conducted. As a result of the study, it was found that polysorbates are mainly used as emulsifiers of the 1st kind and cetostearyl alcohol and lanolin as emulsifiers of the 2nd kind in emulsion medicines.

Conclusions. Considering that synthetic surfactants can cause significant adverse reactions and are strong allergens, it is relevant to study biogenic surfactants as promising emulsifiers and antimicrobial preservatives, to establish their emulsion and preservation ability, which will facilitate the expansion of the range of excipients for emulsion medicines and cosmetics.

Key words: emulsifiers; antimicrobial preservatives; surfactants; emulsions; medicines; medicinal cosmetics.

\section{Список літератури}

1. Walters Y. Dermatologic, cosmeceutic and cosmetic development / Edit. Y.Walters. - 2008. - 644 p.

2. Walters K. Dermatological and transdermal formulations / Edited by Kenneth A. Walters. - New-York- London. 2007. - 565 p.

3. Практикум з технології лікарських косметичних засобів / Т. Г. Калинюк, Є. В. Бокшан, С. Б. Білоус та ін. - К. : Медицина, 2008 . - 184 с.

4. Допоміжні речовини у виробництві ліків : навч. посіб. для студ. вищ. фрармац. навч. закл. / авт. : О. А. Рубан, І. М. Перцев, С. А. Куценко, Ю. С. Маслій; за ред. І. М. Перцева. - Харків : Золоті сторінки, 2016. - 720 с.

5. Промислова технологія лікарських засобів : підручник для студ. фрармац. спец. вищ. навч. закл. / Є. В. Гладух, О. А. Рубан, І. В. Сайко та ін. - Харків : НФаУ «Оригінал», 2016. -630 c.
6. Токсикологічна хімія харчових продуктів та косметичних засобів / С. А. Воронов, Ю. Б. Стецишин, Ю. В. Панченко, В. П. Васильєв. - Л. : Видавництво Львівської політехніки, 2010. - 316 с.

7. Патент України № 71792 A,15. МПК С12 N 1/02, C12 R 1:38 Поверхнево-активний біопрепарат / Карпенко О. В., Мартинюк Н. В., Шульга О. М., Покиньброда Т. Я., Вільданова Р. І., Щеглова Н. С. - № 200331212344; заявл. 25.12.2003; Опубл. 12.2004, Бюл. №12, 2004. C. 4 .

8. Parkinson M. Biosurfactants / M. Parkinson // Biotech. Advs. - 1985. - Vol. 3. - P. 65-83.

9. Sim L. Production and characterization of a biosurfactant isolated from Pseudomonas aeruginosa UW-1 / L. Sim, O. P. Ward, Zy. Li // J. Ind. Microbiol. Biotechnol. - 1997. Vol. 19. - P. 232-238.

ISSN 2312-0967. Фармацевтичний часопис. 2018. № 3 
10. Державний реєстр лікарських засобів України. [Електронний ресурс]. - Режим доступу : http://www.drlz. kiev.ua/

11. Розроблення технології емульгелю з екстрактом пальми сабаль та настойкою софори японської для лікування андрогенної алопеції / О. І. Ярема, М. І. Федоровська, Н. П. Половко // Фармац. журн. - 2016. - № 5. - С. 50-56. 12. Амсріфільні поверхнево-активні речовини на основі промелітового діангідриду як емульгатори емульсійної полімеризації / О.І.Хоменко, О. Г. Будішевська,
Фармацевтична технологія, біофармація, гомеопатія Pharmaceutical technology, biopharmacy, homeopathy

С. М. Варваренко [та ін.] // Вопросы химии и химической технологии. - 2012. - № 4. - С. 40-46.

13. Розробка складу емульсійної основи при створенні лікарського косметичного засобу для застосування при андрогенній алопеції / О. І. Ярема, М.І.Федоровська // Вісник фрармації. - 2014. - № 2 (78). - С. 15-19.

14. Вивчення впливу емульгаторів на реологічні властивості комбінованої м'якої лікарської фрорми хондропротекторної дії / О. І. Міщенко, О. І. Тихонов // Вісник фрармації. - 2011. - № 3 (67). - С. 3-7.

\section{References}

1. Walters Y. Dermatologic, cosmeceutic and cosmetic development. 2008.

2. Walters K. Dermatological and transdermal formulations. New-York-London; 2007.

3. Kalyniuk TH, Bokshan YeV, Bilous SB. Practice on technology of medicinal cosmetics. [Практикум 3 технологіï лікарських косметичних засобів] Kyiv: Meditsyna; 2008. Ukrainian.

4. Ruban OA, Pertsev IM, Kutseko SA, Maslii, YuS. Substances in the manufacture of medicines: a manual for students of higher pharmaceutical educational institutions [Допоміжні речовини у виробництві ліків: навч. посіб.для студентів вищ.фрармац. навч. закл.]. Kharkiv: Zoloti storinky; 2016. Ukrainian.

5. Hladukh YeV, Ruban OA, Saiko IV. Industrial technology of drugs: textbook for the students of pharmacy specialties of higher educational institutions [Промислова технологія лікарських засобів: Підручник для студ. фрармац. спец. вищ. навч. закл.]. Kharkiv: NFaU Oryhinal; 2016. Ukrainian.

6. Voronov SA, Stetsyshyn YuB, Panchenko YuV, Vasyliev VP. Toxicological chemistry of food products and cosmetics [Токсикологічна хімія харчових продуктів та косметичних засобів]. Lviv: Vydavnytstvo Lvivskoi politekhniky; 2010. Ukrainian.

7. Karpenko OV, Martyniuk NV, Shulha OM, Pokynbroda Tla, Vildanova RI, Shchehlova NS, inventors; Surface ac-

tive bioproduct. UA N71792 A, 15. MPK S12 No. 1/02, C12 R 1:38 (Patent) 2004 Dec 25. Ukrainian.

8. Parkinson M. Biosurfactants. Biotech Advs. 1985;3: 6583.

9. Sim L, Ward OP, Li Z. Production and characterization of a biosurfactant isolated from Pseudomonas aeruginosa UW-1. J Ind Microbiol Biotechnol. 1997;19: 232-8.

10. State Register of Drugs of Ukraine [Державний реєстр лікарських засобів України]. Available from: http://www. drlz.kiev.ua/. Ukrainian.

11. Yarema OI, Fedorovska MI, Polovko NP. [Development of emulgel technology with Saw Palmetto extract and Japanese Sophora tincture for androgenic alopecia treatment]. Farm Zhurn. 2016;5: 50-6. Ukrainian.

12. Khomenko OI, Budishevska OG, Varvarenko SM. [Amphiphilic surface active substances based on promelite dianghidride as emulsifiers of emulsion polymerization]. Voprosy khimii i khimicheskoy tekhnolohii. 2012;4: 40-6. Ukrainian.

13. Yarema OI, Fedorovska MI. [Development of emulsion basis for the creation of medicinal cosmetic product for use in androgenic alopecia]. Visnyk farmatsii. 2014;2(78): 15-9. Ukrainian.

14. Mishchenko OI, Tykhonov OI. [Study of the influence of emulsifiers on the rheological properties of a combined semi-solid dosage form of chondroprotective action]. Visnyk farmatsii. 2011;3(67): 3-7. Ukrainian.

Отримано 06.07.2018 